EPiC Series in Engineering
Volume 3, 2018, Pages 1260-1269
HIC 2018. 13th International
Conference on Hydroinformatics

\title{
Assessment and Modeling of Snow Melting Impacts in the French Mediterranean Region - Application to the Var Catchment, France
}

\author{
Qiang MA ${ }^{1}$, Mingxuan DU ${ }^{2}$ Ngoc DUONG VO ${ }^{3}$, Philippe GOURBESVILLE ${ }^{1}$ \\ ${ }^{1}$ Polytech Lab, Nice Sophia Antipolis University, Polytech Nice Sophia, 930 Route \\ de Colles, Sophia Antipolis, 06903, France \\ ${ }^{2}$ Sociéte du Canal de Provence 3099 Route Cézanne, Le Tholonet, 13100, France \\ ${ }^{3}$ Faculty of Water Resource Engineering, University of Science and Technology, the \\ University of Da Nang, Viet Nam
}

\section{Corresponding author:qma@unice.fr}

\begin{abstract}
The climate change impacts leads to the raise of air temperature, which highly affected on the snow melting process in catchment hydrological system. In catchment water resources management, it gains more interests among local managers and hydrological researchers. In this study, based on the daily discharge (2008-2014) collected at the outlet of Var catchment, which located at French Mediterranean region, two flood periods were first identified during one hydrological year. For the flood occurred at spring time, the runoff produced by snow melting from upstream of the catchment has significant contribution to the flood discharge recorded at downstream. To assess the snow melting impacts in this catchment, a distributed deterministic hydrological model (MIKE SHE) was built to simulate the complex hydrological system in Var catchment from 2011 to 2013 with limited data collection. After calibrating the model with the observed discharge, the simulation of MIKE SHE were able to represent the hydrological process in Var catchment including the snow producing and melting process. The simulation results showed that the hypothesis made for the snow melting process, which not only considered the impacts of raise air temperature but also the sunshine intensity was reasonable and suitable to be applied in French Mediterranean region. The modelling approach described in this study could be beneficial to the assessment of snow melting process in the same region or similar watershed.
\end{abstract}


Keywords: Distributed deterministic hydrological modelling, French Mediterranean region, MIKE SHE Snow melting process, Var catchment

\section{Introduction}

Due to the climate change impacts, globally, the air temperature shows an obvious increasing trend. In catchment hydrology, it has significant impact on the snow producing and melting process. The discharge contributed by the snow melting process during one flood event could aggravate the flood peak and cause more serious flood damages. Therefore, for the catchment, which highly affected by this process, the information related to the temporal and special changes of the snow cover and the quantity of the water produced by snow melting are significantly necessary for the local managers to support their decision making.

The snow melting process is one of the main physical processes in hydrological system, which often interacted with other hydrological processes such as rainfallrunoff, evapotranspiration, etc. To analysis its impact on the surface flow and channel flow, simulation implemented by deterministic distributed hydrological model was selected to simulate the hydrological processes in the Var catchment located in the French Mediterranean region. With the increase of computation facilities, the distributed deterministic hydrological model such as MIKE SHE is gaining more interesting by the hydrologist community (Ma et al., 2016). It maintains physical details at each computational cell and considers the distributed hydrological and geological properties cross the catchment (Refsgaard, 1997; Vansteenkiste et al., 2013). The simulation of this model supposes to produce more detail and accurate results and well represent the hydrological processes in any locations of the study area (Graham and Butts, 2005). The main objective of this study is focused on the representation of driving factors which have significant impacts on the changes of snow cover in the catchment and estimation of the quantity of the water produced by snow melting.

\section{Material and Methods}

The Var catchment located at the southeast part of France is the largest catchment at French Mediterranean Alps. It has around $2800 \mathrm{~km}^{2}$ watershed and significant elevation variation from sea level up to over $3000 \mathrm{~m}$ above the sea level (Figure 1). Due to the steep slope distributed in the catchment, the concentration time during the flood event is relatively short (around 24 hours in average). NICE, the fifth biggest city in France located at the outlet of this catchment, which frequently suffered the flood hazards during the flood events in spring and winter. 


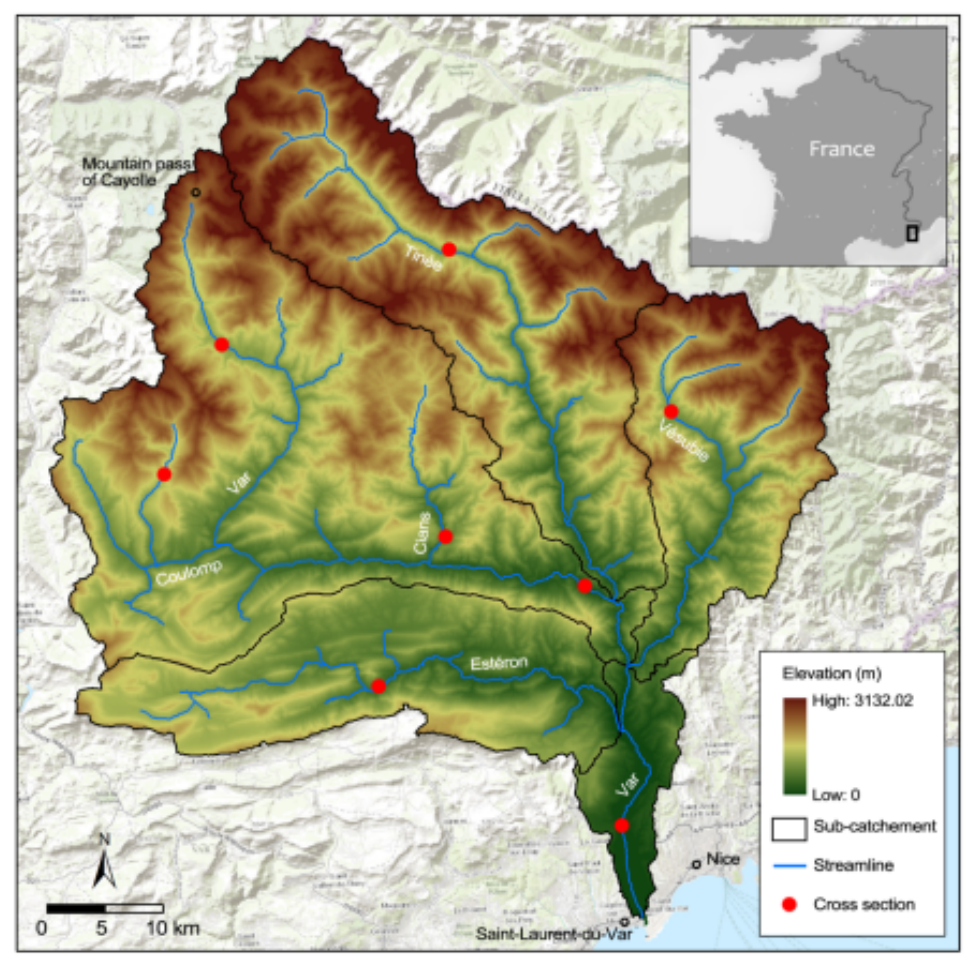

Figure 1: Var River Basin in French Mediterranean Alps.

Based on the observations, the discharge at the mouth of this catchment was fluctuated between $3500 \mathrm{~m}^{3} / \mathrm{s}$ during the flood (recorded at 1994) (CEMAGREF, 1996) and $15 \mathrm{~m}^{3} / \mathrm{s}$ in the dry period (record at 2012). With the channel runoff recorded at the Napoléon III Bridge (Figure 2) at the outlet of the catchment, two flood periods can be simply identified (spring and winter floods) during one hydrological year. 


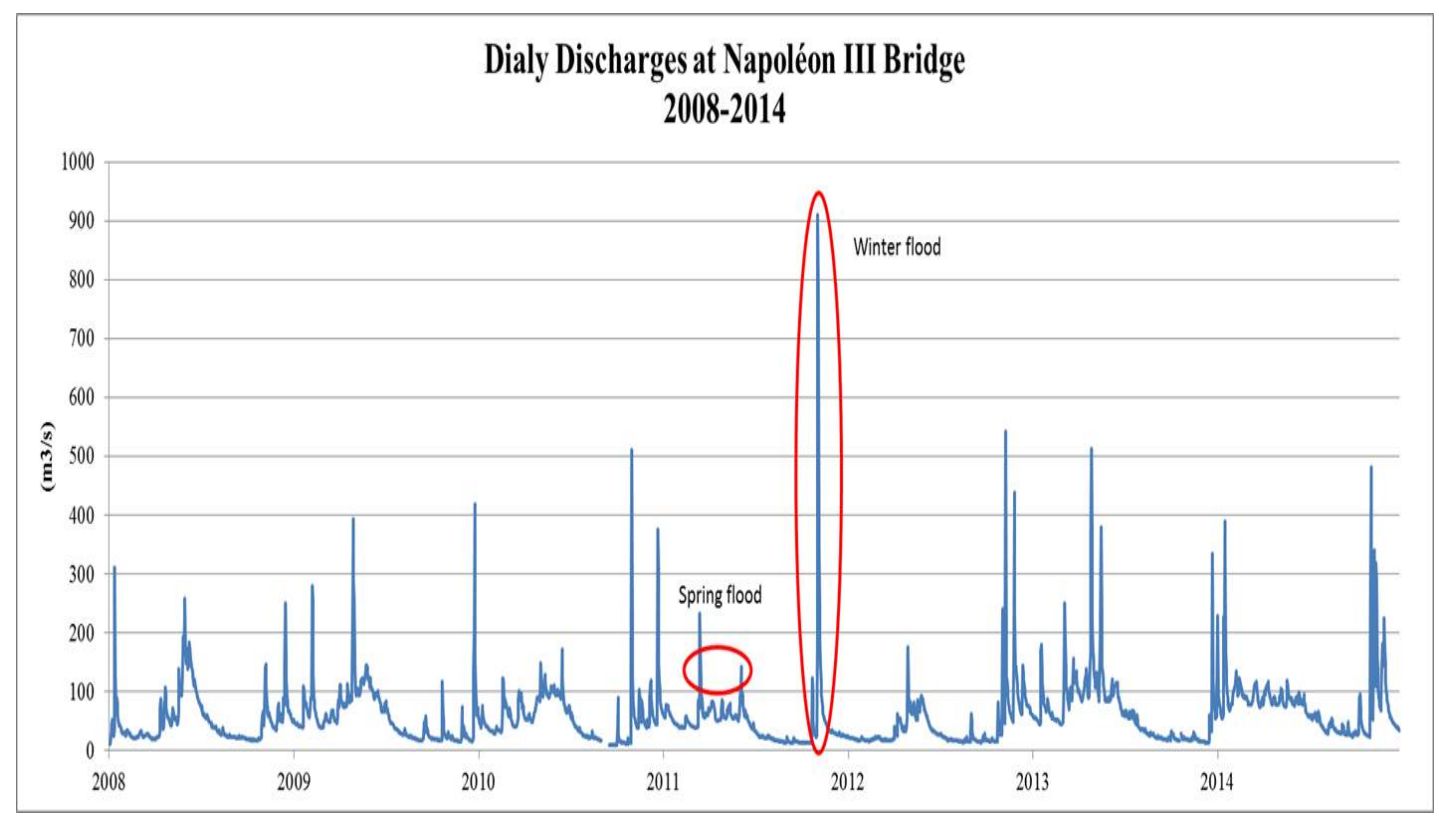

Figure 2: Daily discharges recorded at the outlet of Var River Basin.

Linked with the precipitation data collected from Météo-France, the main causes of the flood in Var catchment could be traced to the high intensity rainfall at certain time periods (e.g. November). However, more detailed assessment shows the properties of those two floods seasons (spring and winter) having slight different causes. Compared to the winter flood, which mainly caused by the high intensity rainfall, the flood discharge during the spring flood was highly influenced by the snow melting processes from the upstream parts of the catchment. To evaluate the snow melting process in Var catchment, two cases of MIKE SHE simulations (with/without snow melting process) were first implemented in this study to identify the role of snow melting process in Var catchment.

In MIKE SHE, the snow melting process is represented by the "Degree-Day process" mainly controlled by the air temperature and the value of "Degree-day Melting or Freezing Coefficient" with the unit of $\mathrm{mm} / \mathrm{C} /$ day. The air temperature recorded in the study area is implemented by the gauging stations distributed over the catchment. The measurement has limitation of only being available until certain high elevation $(1784 \mathrm{~m})$. However, the snow cover in this catchment is usually appeared at summits of the mountains with the high surface elevation. Therefore it is necessary to apply a hypothesis to estimate the air temperature at higher computation point of the catchment. In MIKE SHE model, it allows the user to select the "Temperature Lapse Rate" correction to estimate the air temperature at those cells 
$T_{\text {cell }}$ based on its elevation difference between its elevation and the control gauging station:

$T_{\text {cell }}=T_{\text {station }}+\beta_{\text {cell }} *\left(H_{\text {cell }}-H_{\text {station }}\right)$

where, $T_{\text {station }}$ is the measured temperature at the weather station, $H_{\text {station }}$ is the elevation of the station, $H_{\text {cell }}$ is the elevation of the cell, and $\beta_{\text {cell }}$ is the Temperature Lapse Tate for the cell in unit of degrees per $100 \mathrm{~m}$ of elevation difference. By assessing the air temperature in Var catchment, its Temperature Lapse Rate is around $-0.6^{\circ} \mathrm{C} / 100 \mathrm{~m}$, which is slightly higher than global average value $0.649^{\circ} \mathrm{C} / 100 \mathrm{~m}$ (Figure 3).

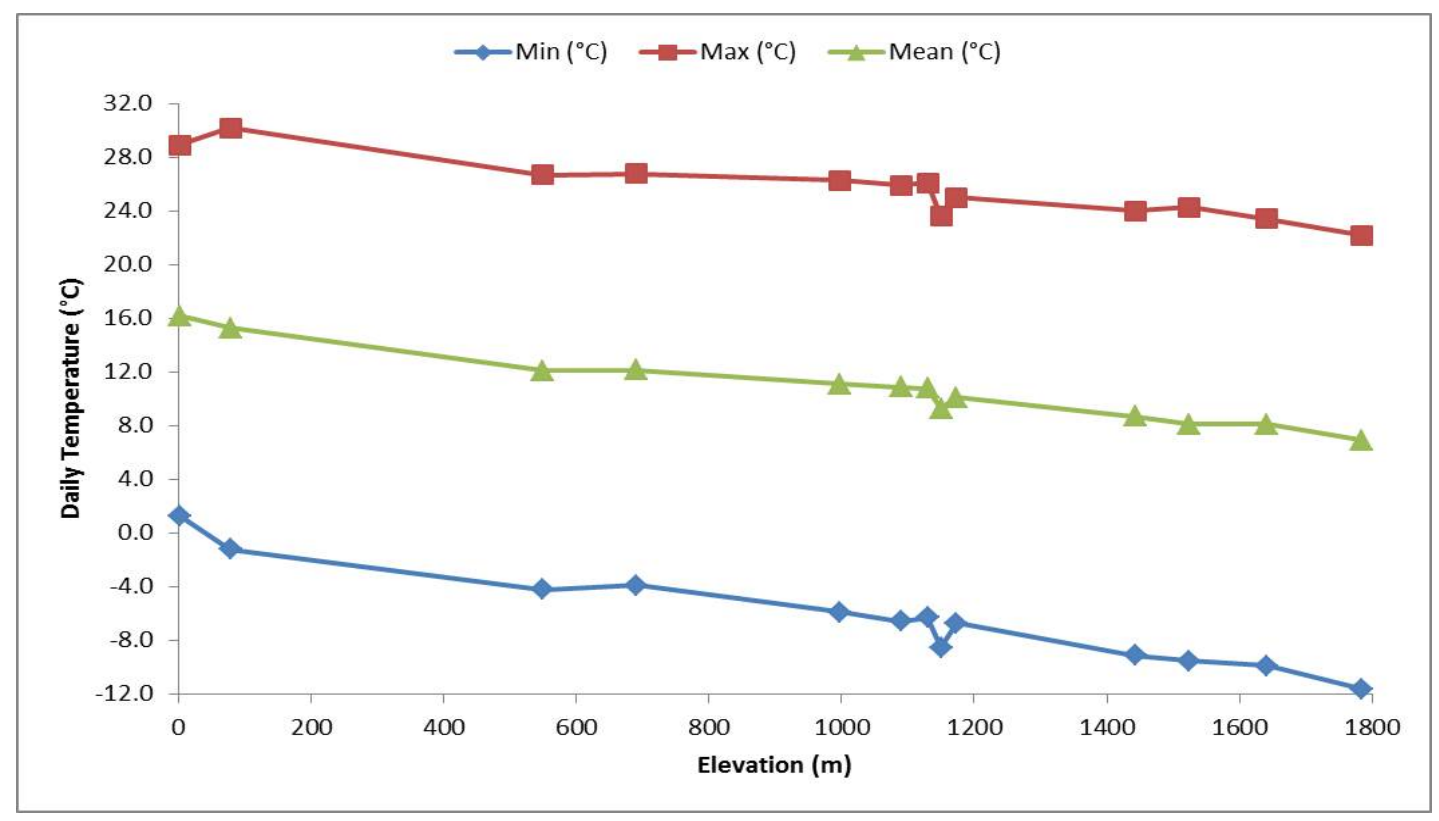

Figure 3: Assessment of the air temperature in Var catchment.

The results shown in Figure 4 clearly indicate the importance of the snow melting process in the Var catchment. During the spring flood period, the simulated discharge showed with red line (with snow melting process) is much higher than the green line (without snow melting) and more closed to the black line (observation). 


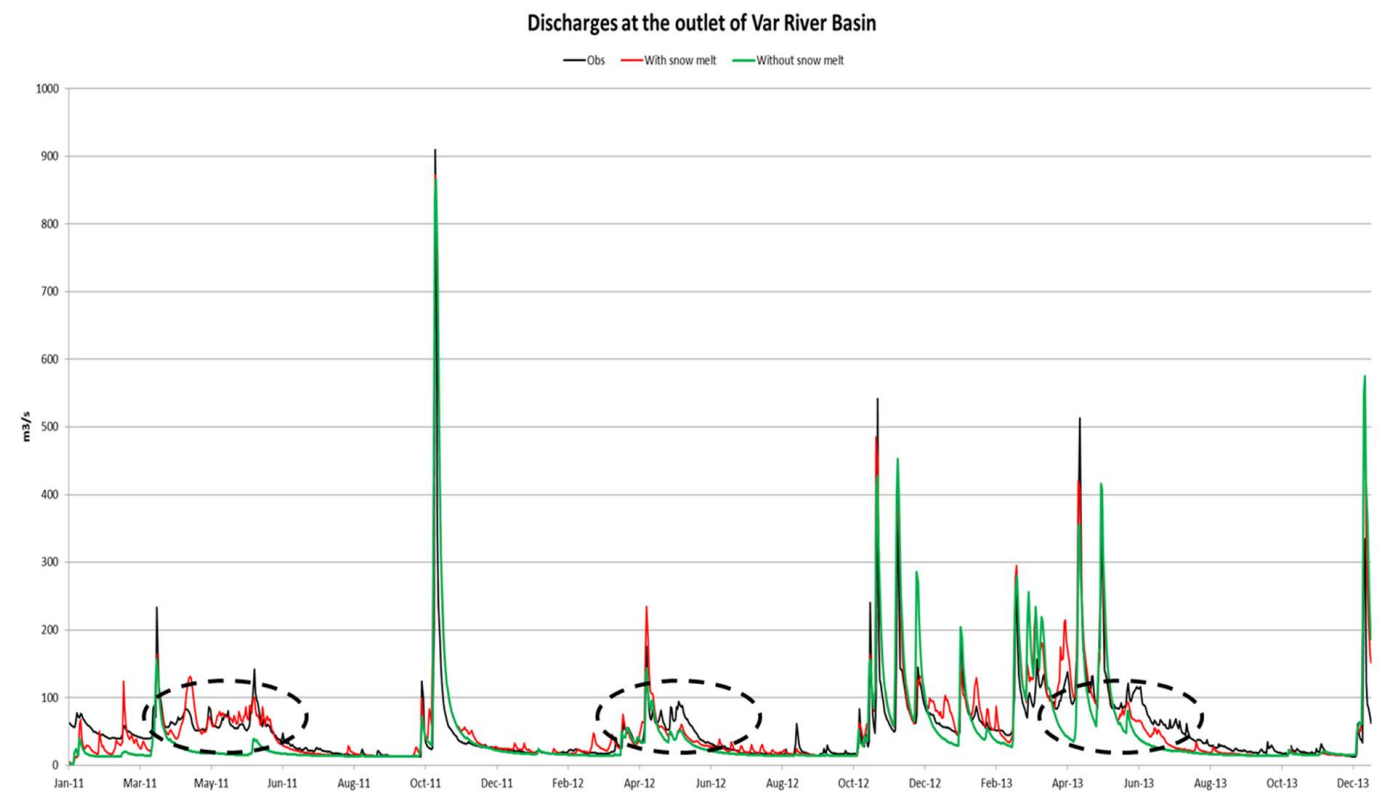

Figure 4: Comparison between the simulation with and without the snow melting process in Var catchment.

Then for calibrating the value of "Degree-day Melting or Freezing Coefficient", based on its definition of "amount of snow that melts per day for every degree the Air Temperature is above the Threshold Melting Temperature (here we kept it as default as $0^{\circ} \mathrm{C}$ )", 4 simulation cases with uniform values were set up to evaluate the influences of this parameters on channel flow in Var catchment (Table 1).

Table 1: Designed values of different cases applied in sensitivity analysis.

\begin{tabular}{|c|c|c|c|}
\hline \multicolumn{4}{|c|}{ Sensitivity analysis of "Degree-day Melting or Freezing Coefficient" } \\
\hline Case 1 & Case 2 & Case 3 & Case 4 \\
\hline $1 \mathrm{~mm} / \mathrm{C} /$ day & $2 \mathrm{~mm} / \mathrm{C} /$ day & $4 \mathrm{~mm} / \mathrm{C} /$ day & $8 \mathrm{~mm} / \mathrm{C} /$ day \\
\hline
\end{tabular}

After this test, distributed values of this parameter were applied in the MIKE SHE simulation of Var catchment to improve the accuracy of the model simulation. In Var catchment, the snow melting process may not only affected by the changing of air temperature, but also the sunshine duration. We assumed that in this catchment the sunshine duration at different location is highly affect by the surface towards. Thus, based on the surface slope direction, we divided the land surface of Var catchment into three categories including "Flat", "Northwards" and "Southwards" (Figure 5) and given different values of "Degree-day Melting or Freezing Coefficient" in each categories. Compared to the categories of "Flat" and "Southward", the snow melting process at the "Northwards" places could be relatively slower. 


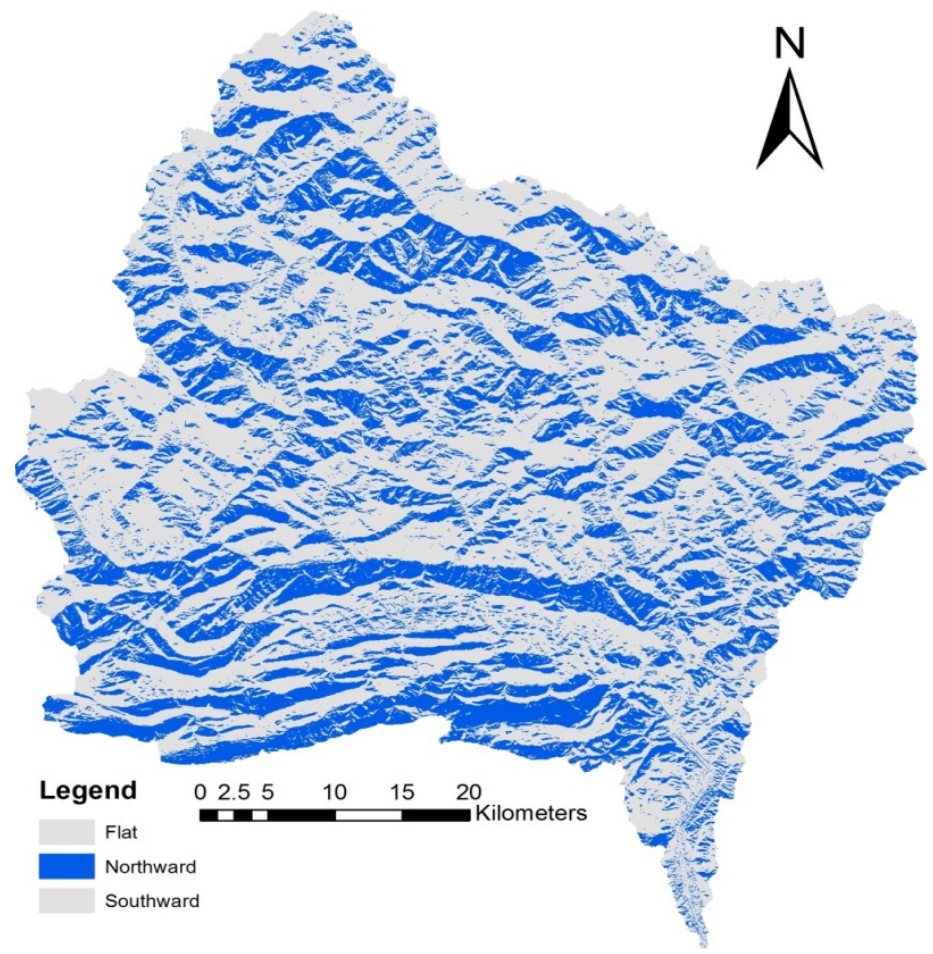

Figure 5: Distributed degree day melting or freezing coefficient in Var catchment.

\section{Results and Discussion}

In Figure 6, the comparison among 4 simulation cases with different values of "Degree-day Melting or Freezing Coefficient" showed the value of this parameter has significant impacts on the speed of the snow melting process. With higher snow melting value, there is less snow storage existing in the catchment at the end of spring time in Var catchment. The red line simulated by $1 \mathrm{~mm} / \mathrm{C} /$ day showed obvious higher discharge during the summer time which is not reasonable in the Var catchment. However, the hydrographs simulated in case 3 and case 4 could produce more reasonable results in this catchment with relative lower channel discharge observed at July and August. The time difference of the snow melting ending point simulated among 4 cases could be longer than 2 months. 


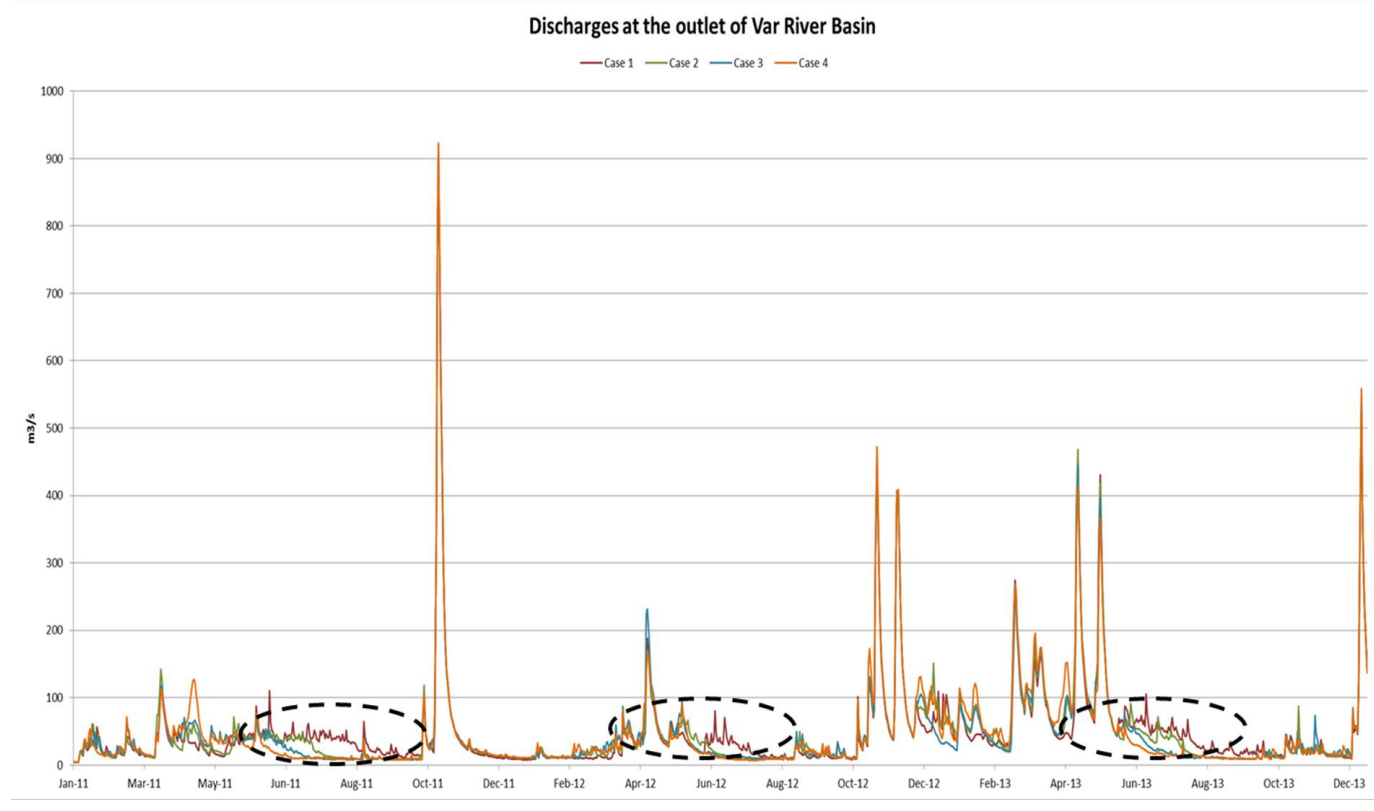

Figure 6: Results of sensitivity analysis of MIKE SHE in Var.

Based on the simulated results of 4 cases, the value of "Degree-day Melting or Freezing Coefficient" in Var catchment is estimated in range of 4 to $6{ }^{\circ} \mathrm{C} / \mathrm{day} / \mathrm{mm}$. Therefore, two more cases of uniform and distributed "Degree-day Melting or Freezing Coefficient" were implemented in the MIKE SHE simulation. The comparison among distributed simulation result (red line), uniformed simulation results (green line) and observation (black line) were showed in Figure 7. The hydrography calculated by distributed snow melting parameters was more closed to the observation, especially in the "Spring Flood" period. Moreover, the 2D snow cover results simulated by distributed snow melting parameters were well represent the snow cover changes observed by the data collected from ALIRHYS project (Figure 8), which indicates our MIKE SHE model in Var catchment having the ability to represent the real phenomenon of the snow melting process in this region. 


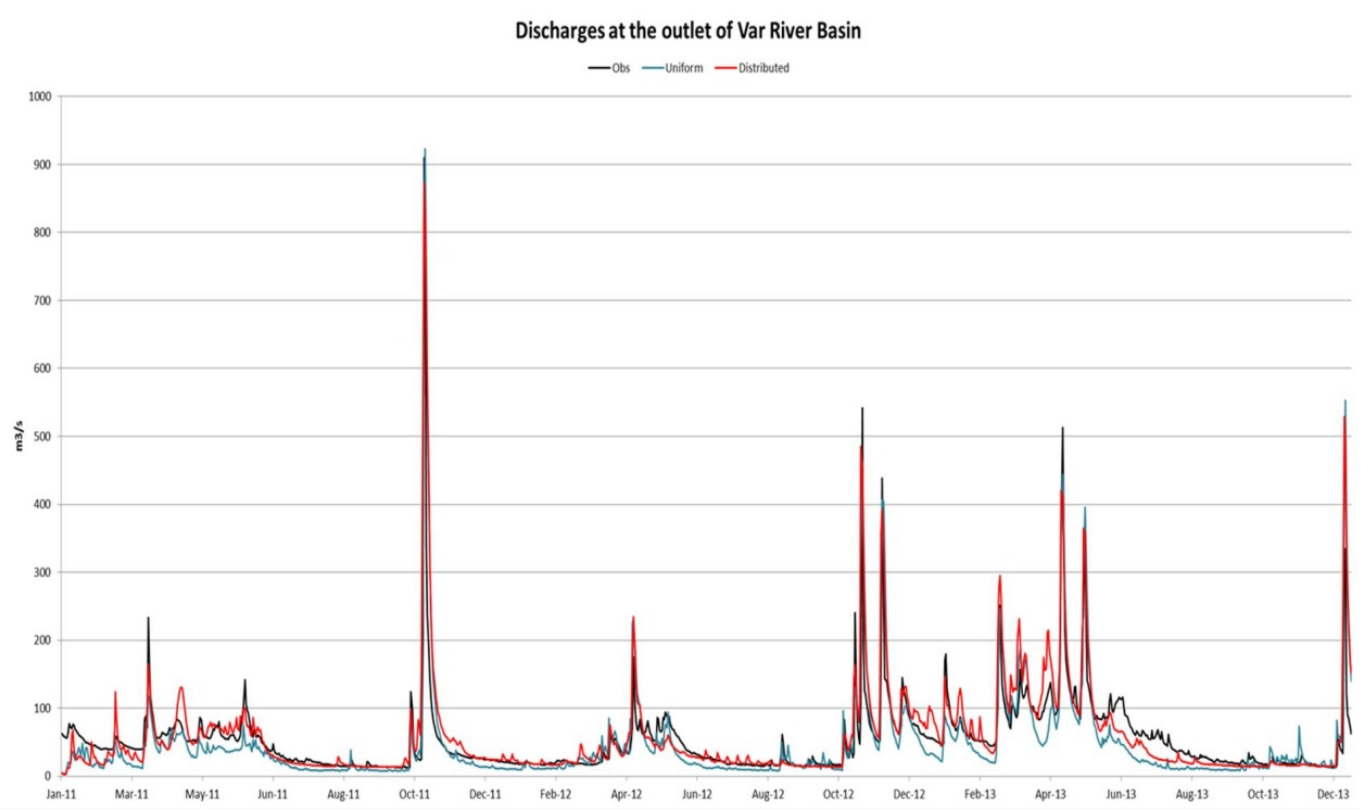

Figure 7: Comparison between uniform and distributed parameters of snow melting in MIKE SHE.

$01 / 10 / 2012$
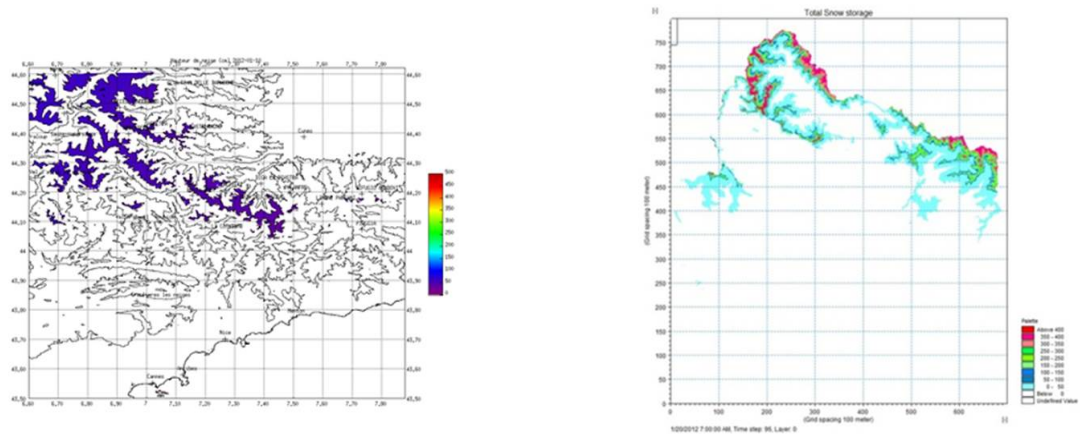

Observation

Simulation

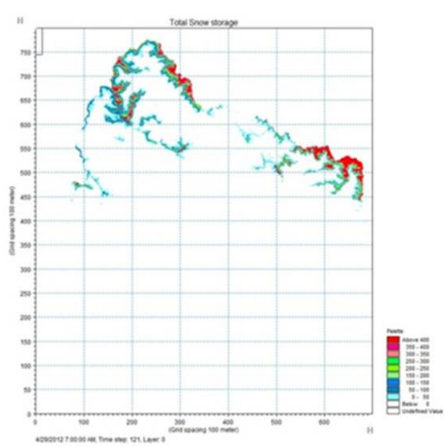

Figure 8: compare the snow cover between observation and simulation. 


\section{Conclusion}

In the Var catchment located at French Mediterranean region, the snow melting process has significant impacts in the hydrological system especially in the "Spring Flood" period. To assess the impacts of snow melting process on the surface flow in this catchment, one deterministic distributed hydrological model (MIKE SHE) was set to represent the hydrological processes. Based on the hypothesises related to the distribution of air temperature and snow melting parameters, the distributed hydrological simulation of MIKE SHE has the ability to represent the real phenomenon in the Var catchment and assess the quantity of the water contribution produced by snow melting to the channel flow in the Var River. The simulation results could be benefits to the local manager who interested in the snow melting production and flood defence in the city located at the downstream part of the catchment. Same modelling strategy to represent the snow melting impacts on catchment hydrological system could also be implemented in other catchment, which has similar characteristics as Var catchment at French Mediterranean region.

\section{Reference}

[1] CEMAGREF, 1996. Etude de la crue du Var du 5 novembre 1994, Aix-en-Provence. 67 $\mathrm{pp}$

[2] DHI 2014 MIKE SHE User's Manual. (Mike by DH, Ed).

[3] Graham, D. N. \& Butts, M. B., 2005. Flexible, integrated watershed modelling with MIKE SHE. In: Watershed Models (V. P. Singh \& D. K. Frevert, eds). Water Resources Publications, Highland Ranch, CO, USA, pp. 245-272.

[4] Ma, Q., Zavattero, E., Du, M.X. \& Gourbesville, P., 2016. Assessment of High Resolution Topography Impacts on Deterministic Distributed Hydrological Model in Extreme Rainfall-runoff Simulation. In 12th International Conference on Hydroinformatics, HIC 2016, Procedia Engineering 154 (2016) $601-608$.

[5] Refsgaard, J. C., 1997. Parameterisation, calibration and validation of distributed hydrological models. Journal of Hydrology. 198 (1-4), 69-97.

[6] Vansteenkiste, T., Tavakoli, M., Ntegeka, V.,Willems, P.,De Smedt, F. \& Batelaan, O., 2013. Climate change impact on river flows and catchment hydrology: a comparison of two spatially distributed models. Hydrol. Process. 27 (25), 3649-3662. 